\title{
PENELUSURAN PAHAM RADIKALISME PADA PROSES PEMBUATAN SURAT KETERANGAN CATATAN KEPOLISIAN SEBAGAI UPAYA PENCEGAHAN TERORISME
}

(Studi Di Unit Pelayanan Administrasi Ditintelkam Polda Sumbar)

\author{
1) Klara Dafidela, ${ }^{2)}$ Ismansyah, ${ }^{3)}$ Fahmiron \\ 1) Program Magister Ilmu Hukum,Universitas Ekasakti, Padang, indonesia \\ Email:kdafidela@yahoo.com \\ ${ }^{2)}$ Program Magister Ilmu Hukum,Universitas Ekasakti, Padang, indonesia \\ Email: ismansyah@gmail.com \\ ${ }^{3)}$ Program Magister Ilmu Hukum,Universitas Ekasakti, Padang, indonesia \\ Email: fahmiron@gmail.com
}

\begin{abstract}
The search for Radicalism in the Making of Police Record Certificates at the Administrative Service Unit of the West Sumatra Police Ditintelkam is carried out based on the applicant's data. When there are applicants for SKCK, after being investigated, it turns out that they have kinship or are related to people who embrace radicalism. Next, an intelligence report is made. Furthermore, the intelligence party will trace the whereabouts of the applicant related to the notion of radicalism. The applicant will be postponed especially the making of the SKCK until the police intelligence report states that the person concerned has never been involved in radicalism or has a relationship with adherents of radicalism. The obstacle in tracing radicalism in making a Police Record Certificate at the Administrative Service Unit of the West Sumatra Police Ditintelkam is in early detection or tracking and evaluation activities. Obstacles in carrying out early detection are in service activities, the system for making SKCK is still done manually and applicant data is not stored in a special storage. Manual data makes it difficult to cross-check or trace the applicant's family and history of crimes. In this system, there is no relationship between the applicant's criminal data and family data. The next obstacle is at the evaluation stage when making intelligence reports. Constraints are reports of links with radical ideologies that are difficult to show the evidence for, because sometimes the links found have been around for a long time.
\end{abstract}

Keywords: Terrorism, SKCK, Radical understanding, Search

\begin{abstract}
ABSTRAK
Penelusuran Paham Radikalisme Pada Pembuatan Surat Keterangan Catatan Kepolisian Di Unit Pelayanan Administrasi Ditintelkam Polda Sumbar dilakukan dengan berdasarkan data data pemohon. Ketika ada pemohon SKCK setelah ditelusuri ternyata mempunyai hubungan kekerabatan atau berkaitan dengan orang orang yang menganut paham radikalisme. Selanjutnya dibuat laporan intelejen. Selanjutnya pihak intelejen akan menelusuri keberadaan dari pada pemohon berkaitan dengan paham radikalisme. Terhadap pemohon akan ditunda terlebih pembuatan SKCKnya sampai laporan intelejen kepolisian menyatakan bahwa yang bersangkutan tidak pernah terlibat paham radikalisme atau mempunyai hubungan dengan
\end{abstract}


penganut paham radikalisme. Hambatan dalam penelusuran paham radikalisme pada pembuatan Surat Keterangan Catatan Kepolisian di Unit Pelayanan Administrasi Ditintelkam Polda Sumbar adalah pada kegiatan deteksi dini atau penelusuran serta evaluasi. Kendala dalam melakukan deteksi dini adalah pada kegiatan pelayanan, sistem pembuatan SKCK masih dilakukan secara manual dan data pemohon tidak disimpan dalam satu penyimpanan khusus. Data manual membuat kesulitan dalam memeriksa silang atau menelusuri keluarga dan sejarah kejahatan yang pernah dilakukan pemohon. Pada sistem ini, belum dapat direlasikan antara data kriminal pemohon dan data keluarga. Kendala selanjutnya adalah pada tahapan evaluasi dilakukan ketika pembuatan laporan intelejen. Kendala adalah laporan keterkaitan dengan paham radikal yang sulit untuk ditampilkan bukti buktinya, karena terkadang keterkaitan yang ditemukan sudah terjadi pada waktu yang lama.

Kata Kunci : Terorisme, SKCK, Paham radikal, Penelusuran

\section{PENDAHULUAN}

Daya tahan nasional ialah sesuatu kondisi yang wajib lalu direalisasikan oleh seberinda warga Indonesia, dengan metode berpedoman pada 3 bawah buat menciptakan daya tahan nasional Indonesia ialah: Pancasila, UUD 1945, serta pengetahuan Nusantara. Selaku salah satu bawah dalam pewujudan Daya tahan Nasional. Sedangkan Pancasila ialah perlengkapan pemersatu bangsa Indonesia dalam pendalaman serta pengamalannya sedang belum seluruhnya cocok dengan nilai-nilai bawah Pancasila, apalagi dikala ini kerap diperdebatkan.

Pandangan hidup pancasila mengarah terbangun dengan terdapatnya kelompokkelompok khusus yang memajukan faham bebas ataupun independensi tanpa batasan, begitu pula faham keimanan yang bertabiat radikal. Terbentuknya beberapa permasalahan yang bertabiat radikal, semacam insiden Bom Bali, Bom Kuningan, Bom Marriot serta bentrokan dengan bermacam corak serta wujud sikap bagus dalam lingkup nasional, lingkup wilayah, ataupun dampingi masyarakat warga membuktikan alangkah besar ancaman yang dialami oleh bangsa serta negeri serta alangkah jauh dampak bencana yang wajib dialami orang. Oleh sebab itu kecermatan nasional wajib ditingkatkan, dengan semenjak dini memperjuangkan supaya peristiwa-peristiwa bentrokan yang bawa beban serta kesusahan untuk orang janganlah terulang kembali ataupun sangat tidak bisa diminimalisasi. ${ }^{1}$

Kecermatan nasional hendak senantiasa terpaut dengan keamanan nasional. Berartinya keamanan nasional pada dasarnya menyangkut 3 faktor, ialah: independensi negeri, integritas bangsa, keamanan dan penjagaan pembangunan nasional. ${ }^{2}$ Mutu kesiapan serta kesiapsiagaan bangsa buat mengetahui, mengenali, mengestimasi semenjak dini serta melaksanakan kelakuan penangkalan dini kepada bermacam wujud serta watak kemampuan bahaya ialah dimensi kecermatan nasional. Kenaikan pada kecermatan nasional lewat penemuan dini ini hendak bisa mendesak pada kenaikan mutu pembangunan tercantum dengan terwujudnya kemantapan keamaman.

Aplikasi kecermatan nasional kepada radikalisme Polri sudah melakukan lewat

${ }^{1}$ Tim Penyusun, Buku Panduan Mata Kuliah Kewaspadaan Nasional. Materi Pokok 2: Manajemen Konflik. Lemhannas RI. 2014, hlm. 4

"'Membangun Sikap Waspada Bangsa Indonesia," http://www.polarhome.com/pipermail/nusantara//000749.html diakses pada tanggal 12 April 2021 
penemuan dini kepada ancaman-ancaman yang diprediksi memiliki faktor radikal. Tetapi sepanjang ini, aksi refresif saja yang dikedepankan serta pengungkapan kasus-kasus terorisme yang sudah dicoba tidak memajukan penangkalan, sebab bila permasalahan terorisme telah terjalin, aksi refresif dilaksanakan dengan memercayakan gerombolan Densus 88, alhasil mengarah belum berlagak cermas kepada serangan- serangan yang hendak timbul dari golongan radikal. Aksi melindungi dari wujud kecermatan nasional ini salah satunya merupakan lewat pembuatan Pesan Penjelasan Memo Kepolisian (SKCK).

Pesan Penjelasan Memo Kepolisian (SKCK), tadinya diketahui selaku Pesan Penjelasan Lagak Bagus (disingkat SKKB) merupakan pesan penjelasan yang diterbitkan oleh Polri yang berisikan memo kesalahan seorang. Dulu, sewaktu bernama SKKB, pesan ini cuma bisa diserahkan yang tidak atau belum sempat terdaftar melaksanakan aksi kesalahan sampai bertepatan pada dikeluarkannya SKKB itu. SKKB legal sepanjang 6( 6) bulan.

Bawah Hukum pembuatan Pesan Penjelasan Memo Kepolisian (SKCK) itu sendiri merupakan Artikel 15 bagian (1) graf k Hukum Nomor. 2 Tahun 2002 Mengenai Kepolisian yang melaporkan Polri dengan cara biasa berhak menghasilkan pesan permisi serta ataupun pesan penjelasan yang dibutuhkan dalam bagan jasa berikutnya merupakan bersumber pada Skep Kapolri Nomor. Angket: Skep atau 816 atau IX atau 2003 bertepatan pada 17 September 2003 mengenai petunjuk alun-alun publikasi SKCK serta PP Nomor. 50 tahun 2010, mengenai Pemasukan Negeri Bukan Pajak.

Tiap warga Indonesia yang dapat dibilang telah berusia diwajibkan buat membuat Pesan Penjelasan Memo Kepolisian (SKCK) untuk menolong andil kepolisian buat mengamati dalam melempangkan supermasi hukum yang terdapat di Indonesia dengan seimbang cocok dengan hukum UUD 1945 dalam penegak hukum yang berkridebel serta selaku pengayom warga yang menginginkan keamanan. Andil berarti pembuatan publikasi Pesan Penjelasan Memo Kepolisian (SKCK) merupakan dalam pendeteksian dini (early detection). Dasar guna Intelijen Keamanan mempunyai wewenang dalam menghasilkan Pesan Memo Penjelasan. Pendeteksian dini dicoba paling utama kepada mengerti radikalisme selaku pangkal dari perbuatan kejahatan terorisme.

Terorisme ialah salah satu wujud kesalahan yang jadi pancaran di bumi, sebab aksi itu memakai kekerasan ataupun mengecam dengan kekerasan kepada warga ataupun keamanan nasional apapun motifnya, alhasil menghasilkan perasaan rawan serta kekhawatiran. ${ }^{3}$ Semenjak berdirinya Negeri Kesatuan Republik Indonesia (NKRI), Indonesia tidak sempat bebas dari bahaya teror serta banyak pihak memperhitungkan Indonesia hadapi bahaya terorisme semenjak dini tahun 2000-an dan jadi pusat atensi bumi sebab selaku incumbent serta follower dalam aspek terorisme. ${ }^{4}$ Pada dasarnya, terorisme ditatap selaku kesalahan luar lazim (Extraordinary Crime) serta ialah sesuatu wujud perang garis besar, sejenis perang dingin dengan kedudukan pengganti yang berlainan. Wujud teror sendiri bisa dicoba dengan bermacam metode aksi, antara lain ancaman serta bahaya, penganiayaan, penyanderaan, peledakan, pemboman, pemalsuan, serta pembakaran. Pada era saat ini, kejadian terorisme di Indonesia bukan ialah perihal yang asing lagi.

Tidak menyudahi di sana saja, ada sebagian permasalahan terorisme di Indonesia pula

\footnotetext{
${ }^{3}$ Petrus Reinhard Golose, Deradikalisasi Terorisme, Humanis, Soul Approach dan Menyentuh Akar Rumput, YPTIK, Jakarta, 2009, hlm 12

${ }^{4}$ Wahid, e.l., Kejahatan Terorisme Perspektif Agama. Hukum, Refika Utama, Bandung, 2004, hlm 9
} 
bersinambung pada rentang waktu durasi 2015 hingga 2016, antara lain: (1). April 2015, Bom di area Kawasan tinggal di Tanah Kakak, Jakarta; (2). Juli 2015, Bom di Mall Alam Sutera, Tangerang; (3). 28 Oktober 2015, Bom kembali meledak di Mall Alam Sutera, Tangerang; (4). November 2015, Bom di Jalur Raden Intan, Duren Sawit, Jakarta; (5). 14 Januari 2016, Bom di Sarinah, Thamrin, Jakarta; serta (6). 5 Juli 2016, Bom di Markas Kepolisian Reserse Kota Surakarta, Surakarta, Jawa Tengah.

Memandang banyaknya kesalahan terorisme, hingga butuh dicoba counter terrorism ataupun perang garis besar melawan terorisme. Dalam perihal penyelesaian terorisme oleh penguasa salah satunya merupakan dengan pemberlakukan Hukum No 5 Tahun 2018 mengenai Pergantian Atas Hukum No 15 Tahun 2003 Mengenai Penentuan Peraturan Penguasa Pengganti Hukum No 1 Tahun 2002 Mengenai Pemberantasan Perbuatan Kejahatan Terorisme Jadi Hukum.

Ada sebagian pendekatan, Angkatan darat (AD)' ha Aljunied menarangkan terdapat 2 pendekatan penting dalam perang garis besar melawan terorisme. Awal, pendekatan keras (Hard Approach), membutuhkan keikutsertaan raga yang mematahkan konsep merusak teroris, semacam pengeboman. Lewat legislatif, yudikatif serta administrator yang membuktikan perang negeri melawan terorisme, negeri modern memakai tata cara semacam penahanan, pengawasan, intelijen serta penangkapan buat mematahkan inisiatif para teroris. Kedua, pendekatan lunak (Soft Approach), ialah usaha buat mengurangkan pandangan hidup teroris lewat artikel anti pandangan hidup, kepada pandangan hidup radikal yang mendesak kekerasan politik.

Dalam kondisi penangkalan terorisme, warga memiliki berperan besar di dalam area sosial serta jadi entitas yang amat vital. Warga disini berfungsi memutuskan ideologisasi, mengetahui kehadiran golongan teroris, ataupun dalam mengendalikan perbuatan cula jaringan kekerasan ini. Kesertaan warga serta area pula penting dalam menguak jaringan terorisme. Semacam misalnya, penahanan jaringan Thorik di Tambora, Jakarta Barat. Penahanan itu tidak bebas dari kedudukan warga buat ikut serta memecahkan jaringan terorisme. Tidak hanya itu, penahanan Ridwan nama lain Ismail Tiongkok yang berawal dari informasi masyarakat. ${ }^{5}$

\section{METODE PENELITIAN}

Spesifikasi penelitian adalah deskriptif analitis, dengan metode pendekatan yuridis normative didukung oleh yuridis empiris. Jenis data yang digunakan adalah data sekunder dan data primer. Data sekunder diperoleh dari studi dokumen, data primer diperoleh dengan cara wawancara. Data yang diperoleh kemudian dianalisa secara kualitatif.

\section{PEMBAHASAN}

A. Penelusuran Paham Radikalisme Pada Pembuatan Surat Keterangan Catatan Kepolisian Di Unit Pelayanan Administrasi Ditintelkam Polda Sumbar

Radikalisme serta intoleransi yang terjalin di tengah- tengah warga yang bertanggungjawab bukan saja penguasa lewat pihak polri, tetapi amat dibutuhkan kesertaan semua bagian warga. Dengan cara kelembagaan, penangkalan serta penindakan kejahatan terorisme dicoba oleh petugas negeri begitu juga diatur dalam Hukum No 9

\footnotetext{
No. 2. Juni 2011

5 Hery firmansyah, Upaya Penanggulangan Tindak Pidana Terorime, Jurnal Mimbar Hukum, Vol. 23
} 
tahun 2013 mengenai penangkalan serta pemberantasan perbuatan kejahatan pendanaan terorisme serta peraturan kepala negara No 12 tahun 2012 mengenai pergantian atas Perpres No 46 tahun 2010 mengenai Tubuh Nasional Penyelesaian terorisme.

Polri bekerja membagikan jasa keamanan serta kedisiplinan pada warga, tercantum dalam pemberantasan golongan radikal serta intoleransi di Indonesia. Dengan cara biasa langkah- langkah yang direncanakan oleh Polri bermaksud buat penangkalan timbulnya kekerasan yang bermuara pada bentrokan sosial. Penindakan golongan radikal serta intoleransi ialah salah satu program optimalisasi kelakuan mengarah Polri yang terus menjadi professional, modern serta terpercaya (Promoter) lewat guna Bintara Pengajar Keamanan serta Kedisiplinan Warga yang disingkat Bhabinkamtibmas.

Polri ialah institusi penguasa yang memiliki kewajiban utama penegakkan hukum, menjaga kamtibmas dan meberikan proteksi, dukungan serta jasa pada warga. Dalam melakukan kewajiban utama itu hingga dalam institusi Polri dibutuhkan fungsi- fungsi kepolisian yang memiliki area kegiatan tiap-tiap yang silih terpaut serta terstruktur. Guna kepolisian itu salah satunya merupakan Intelijen keamanan ataupun yang lazim diucap intelkam. Guna ini ialah salah satu guna kepolisian. Tutur intelijen berawal dari bahasa Inggris "Intelligence" yang dengan cara literal berarti intelek. Dengan cara spesial yang berhubungan dengan usaha mengamankan Negeri serta Bangsa" 6

Bersumber pada penafsiran di atas dimengerti kalau Intelijen keamanan ialah bagian integral dari guna organik Polri yang menyelenggarakan aktivitas serta pembedahan Intelijen bagus berbentuk pelacakan, penjagaan ataupun penggalangan dalam aspek keamanan untuk kebutuhan penerapan kewajiban operasional serta manajemen Polri dalam bagan menciptakan keamanan dalam negara. Guna intelkam ialah guna intelkam yang bekerja Selaku Mata serta Kuping kesatuan Polri yang bertanggung jawab melakukan penemuan dini serta membagikan peringatan permasalahan serta kemajuan permasalahan serta pergantian kehidupan sosial dalam warga, serta pula bekerja mengenali bahaya, kendala, ataupun halangan kepada Kamtibmas.

Suasana kamtibmas serta perbuatan kejahatan mempunyai kecendrungan bertambah dari tahun ke tahun seiringan dengan kemajuan bermacam pandangan kehidupan warga, sedangkan itu suasana keamanan serta kedisiplinan yang mendukung di area merupakan telak, buat menciptakan untuk mensupport terselenggaranya pembangunan wilayah hingga ke tingkatan nasional tercantum berjalannya cakra rezim serta perekonomian bangsa.

Badan intelijen wajib menghasilkan badan yang runcing serta cermat alhasil seluruh mungkin mengenai kemajuan kamtibmas bisa diduga oleh kepolisian. Hingga dituntut kedudukan serta guna intelkam dalam melaksanakan tugasnya dalam mengalami kemajuan paradigma kamtibmas yang terjalin di area tugasnya tiap-tiap. Dalam aplikasi sistem penguasa Indonesia andil intelijen merupakan membagikan peringatan (early detection and early warning system) mengenai keadaan yang berhubungan dengan bahaya kepada negeri dari dalam ataupun dari luar. Dengan cara yuridis hingga kedudukan intelijen bila diterjemahkan dari tujuan Intelijen Negeri yang tercatat dalam UU No 17 tahun 2011 mengenai Intelijen Negeri Artikel 5 dituturkan kalau: Tujuan Intelijen Negeri

\footnotetext{
${ }^{6}$ WJS. Poerwaadarminta, Kamus Umum Bahasa Indonesia, (Jakarta : Bumi Aksara, 2009), h. 362
} 
merupakan mengetahui, mengenali, memperhitungkan, menganalisa, memaknakan, serta menyuguhkan Intelijen dalam bagan membagikan peringatan dini buat mengestimasi bermacam mungkin wujud serta watak bahaya yang potensial serta jelas kepada keamanan serta keberadaan bangsa serta negeri dan kesempatan yang terdapat untuk kebutuhan serta keamanan nasional.

Kepolisian dalam usaha pemberantasan cara radikalisme dengan metode menetralisi banyak orang yang berpotensi jadi orang yang melaksanakan perekrutan dengan mengidentifikasi golongan inti, pendukung serta partisan dengan melemahkan pandangan hidup radikal yang mereka coba sebarkan dengan membuat pandangan hidup yang terkini yang bertabiat berimbang dengan metode memblokir alat social serta melaksanakan penyebaran pandangan hidup aduan itu pada golongan warga yang rentan terserang radikalisme lewat alat sosial serta melaksanakan edukasi serta konseling, dengan menguasai kondisi sosial serta adat yang terdapat hendak lebih gampang buat melaksanakan edukasi serta konseling disetiap susunan warga dengan menggunakan kebajikan local dan menjaga alat yang jadi alat penyebaran mengerti radikalisme ialah alat social, alat elektronik serta alat cap. Tidak hanya itu, Polri pula melaksanakan usaha pencarian mengerti radikalisme lewat pembuatan SKCK di kantor polisi buat dicoba aksi hukum.

Jasa pembuatan SKCK ialah salah satu kewajiban dari Direktorat Intelejensi Keamanan (INTELKAM) di Kepolisian Polda Sumbar. Jasa pembuatan SKCK pada hakikatnya merupakan serangkaian aktivitas, sebab itu cara jasa itu berjalan dengan cara teratur serta berkelanjutan, mencakup semua kehidupan badan dalam warga. Cara yang dimaksudkan dicoba sehubungan dengan silih penuhi keinginan antara akseptor layanan SKCK serta donatur jasa SKCK.

SKCK ialah kependekan dari Pesan Penjelasan Memo Kepolisian. SKCK merupakan pesan penjelasan sah yang diterbitkan oleh polri lewat guna Intelkam pada seseorang pemohon ataupun masyarakat warga buat menerangkan mengenai terdapat atau tidak terdapatnya memo sesuatu perseorangan ataupun seorang dalam aktivitas kejahatan ataupun kesalahan. Tercantum pula disini pencarian mengerti radikalisme yang dianut oleh seorang yang memohonkan SKCK serta keluarganya.

Pada permohonan pembuatan SKCK seseorang pemohon wajib memenuhi dengan informasi informasi keluarganya. Ada pula arsip arsip yang wajib di informasikan antara lain merupakan Metode Periksa Jemari atau Saran Memo Kepolisian dari Polda atau Polres setempat cocok alamat KTP. Bersumber pada arsip ini hendak bisa ditelusuri memo pidana ataupun asumsi kesalahan yang sempat dicoba oleh pemohon. Berikutnya merupakan duplikat KTP, pasport, kartu keluarga. Bersumber pada keseluruhan arsip ini dicoba pencarian mengerti radikalisme yang dianut. Perihal itu diamati dari pencarian keluarga pemohon itu. Bila ada badan keluarga yang sempat ataupun diprediksi mempunyai mengerti radikalisme hingga pemohon SKCK pula dicurigai menganut mengerti radikalisme. Bersumber pada pasport yang dipunyai pemohon hendak diamati memo ekspedisi dari pemohon ke luar negara. Bila ada memo ekspedisi yang dicoba dicurigai merupakan berhubungan dengan negeri negeri yang menganut mengerti radikalisme hingga pemohon pula bisa dicurigai selaku bagian dari mengerti radikalisme. kepada yang dicurigai menganut mengerti radikalisme hingga aksi hukum yang dicoba 
merupakan membuat informasi intelejen. Berikutnya pihak intelejen hendak menelusuri kehadiran dari pada pemohon berhubungan dengan mengerti radikalisme. kepada pemohon hendak ditunda terlebih pembuatan SKCKnya hingga informasi intelejen kepolisian melaporkan kalau yang berhubungan tidak sempat ikut serta mengerti radikalisme ataupun memiliki ikatan dengan pengikut mengerti radikalisme. Cocok gambar yang disyaratkan dalam pembuatan SKCK merupakan bercorak dimensi 4 x 6 centimeter sebesar 6 (6) lembar dengan kerangka balik merah, berpakaian santun, nampak wajah, serta kedua kuping. Untuk pemohon yang menggunakan kerudung, cocok gambar wajib nampak wajah serta tidak bisa memakai tudung. Tujuannya merupakan supaya wajah pemohon bisa nampak nyata alhasil bisa ditelusuri kesesuai antara arsip yang diserahkan serta pemohon yang berhubungan.

Semacam yang sempat terjalin di bagian jasa administrasi Ditintelkam Polda Sumbar dimana kala terdapat pemohon SKCK sehabis ditelusuri nyatanya memiliki ikatan kekerabatan dengan Arif Belas kasih Juri baya 29 tahun, Minang, kel. Tanjung Baringin Kec. Lubuk Sikaping Kab. Pasaman, yang mana Arif Belas kasih Juri ialah seseorang pendukung aksi teroris ISIS serta ialah dekap Salafi Langgar Jalur Tangah hanya kota Bukittinggi. Bersumber pada penjelasan pangkal itu bisa dikenal kehadiran dari Arif Belas kasih Juri itu. Pada pembuatan SKCK bagian jasa administrasi Ditintelkam Polda Sumbar pula sempat ditemui pemohon yang berhubungan dengan orang orang yang menganut mengerti radikalisme.

Suatu mutu jasa pembuatan SKCK yang diharapkan oleh akseptor layanan menginginkan tingkatan kelebihan dari jasa pembuatan SKCK yang diterima dari jasa yang diperoleh tadinya. Hingga dari itu, bila jasa pembuatan SKCK itu melewati impian warga selaku akseptor layanan hingga mutu jasa yang diserahkan hendak memperoleh presepsi sempurna dari para akseptor layanan. Kebalikannya, bila jasa itu tidak cocok dengan impian akseptor layanan, hingga presepsi dari para akseptor layanan hendak tidak sempurna. Jasa yang bagus dicoba dengan tidak melalaikan tindakan kehati hatian dari aparat dalam pengecekan riwayat kesalahan pemohon serta riwayat mengerti radilkal yang dianutnya.

Terdapatnya format utama mutu jasa, bisa jadi dorong ukur bagus ataupun kurang bagusnya mutu jasa yang diserahkan oleh aparat jasa pembuatan SKCK di Polda Sumbar. Alhasil ke depan pihak donatur jasa dalam perihal ini Polda Sumbar bisa tingkatkan mutu pelayanannya dalam pembuatan SKCK. Dengan sedemikian itu, jasa yang sudah diadakan oleh kepolisian ini, bisa menolong kepolisian dalam menelusuri terdapat atau tidaknya radikalisme pada pemohon SKCK.

Perihal ini dicoba oleh Polri dalam bagan mencegah warga serta kebutuhan biasa, tercantum menghindari bertumbuhnya mengerti yang tidak cocok dengan arti anutan agama serta nilai- nilai Pancasila, sekalian melindungi kesempurnaan Negeri Kesatuan Republik Indonesia. Penindakan terorisme dilaksanakan Polri lewat 2 pendekatan ialah pendekatan keras (hard approach) serta pendekatan lunak (soft approach). Pendekatan Keras merupakan teror wajib ditindak, namun dengan senantiasa menjunjung besar code of conduct atau rule of engagement alhasil apa juga yang dicoba dalam melawan terorisme terbebas dari perkara membela serta anti alhasil memperoleh keabsahan serta legalitas. 
Pendekatan keras (hard approach) sepanjang ini tidak seluruhnya efisien dalam penyelesaian terorisme. Tidak hanya cedera sebab lenyapnya kaitan calo apabila jumlah pelakon yang tertembak mati banyak, perihal ini pula membatasi data mengenai sel serta badan teror itu. Tidak hanya itu, bertembakan mati teroris mencadangkan gelisah serta marah keluarga dan komunitas yang dibiarkan.

Hasil Strategi serta Reaksi Polri dari penindakan Terorisme sepanjang ini nyaris seluruh permasalahan besar terbongkar, jaringan beberapa besar ditemukan serta dilumpuhkan serta bisa menghindari pelakon saat sebelum bertindak tetapi perkara yang diketemukan merupakan Polri belum bisa membatasi bertumbuhnya jaringan terorisme serta membatasi penyebaran pandangan hidup radikal, tidak hanya itu perbandingan polisi serta masyarakat di Indonesia amat tidak logis. Persisnya, 1: 1. 000. Satu polisi buat 1.000 orang masyarakat. Sementara itu, bagi Perserikatan Bangsa- Bangsa (PBB), perbandingan idealnya merupakan 1: 350. Dengan jumlah yang minimun itu hingga jasa serta proteksi pada masyarakat memanglah kemudian tidak dapat maksimum.

Alhasil membutuhkan strategi yang bisa menghindari buat menghindari ialah dengan pendekatan lunak. Pendekatan lunak (soft approach) umum dicoba lewat program deradikalisasi semacam memajukan guna intelijen serta pembinaan warga tingkatan mabes serta kewilayahan yang melingkupi kemitraan, dan kebijaksanaan berplatform persetujuan serta legalitas khalayak, bukan semata- mata mempraktikkan peraturan. Berikutnya butuh aksi melindungi bukan reaktif, pendekatan interagensi serta menguatkan kecermatan warga supaya tidak terbawa-bawa terorisme serta tidak mengasihani pada aksi terorisme. Berikutnya perkara pada kecermatan nasional lewat penemuan dini kepada kelakuan teroris merupakan belum terdapatnya kebijaksanaan hal perbuatan kejahatan penghasutan kepada warga lewat alat alhasil hendak membatasi usaha penangkalan kepada masuknya pandangan hidup radikalisme. Perihal ini diamati dari bahaya sungguh-sungguh radikalisme yang diiringi dengan menggunakan perkembangan teknologi dimana faham anutan radikal, dengan cara leluasa terhambur di internet.

Usaha pemberantasan dicoba Polri, ialah dengan melaksanakan langlang cyber, konseling ataupun pemasyarakatan, penataran pembibitan serta kampanye eksploitasi internet dengan bijaksana. Kemudian melaksanakan bimbingan serta komunikasi ke penggiat medsos, para netizen, akademi besar, alat massa serta badan yang terpaut, provider seluler serta yang lain. Alhasil, mereka dapat ikut berfungsi mengkampanyekan anti hoax serta melindungi ruang khalayak internet supaya senantiasa segar alhasil terwujud kedisiplinan bersama.

\section{B. Hambatan Dalam Penelusuran Paham Radikalisme Pada Pembuatan Surat Keterangan Catatan Kepolisian Di Unit Pelayanan Administrasi Ditintelkam Polda Sumbar}

Pengawasan Kepala Dasar INTELKAM ialah guna organik dari manajemen, yang silih terpaut dengan pemograman pada Polda Sumbar. Pengawasan ini dicoba buat bisa menilai dari hasil penerapan jasa pembuatan SKCK yang didapat dengan cara berakal untuk (berdaya guna) serta sukses untuk (efisien) cocok dengan konsep yang sudah didetetapkan tadinya. Dengan terdapatnya pengawasan hingga bisa meminimalisir terdapatnya mungkin penyalahgunaan ataupun menjauhi penyimpangan dan kekeliruan yang bisa jadi terjalin. 
Bersumber pada Peraturan Kepala Kepolisian Negeri Republik Indonesia No 22 Tahun 2010 pada artikel daya muat bagian 1 serta 2, Ditintelkam (Direktorat Intelijen serta Keamanan) Subbagian Jasa Administrasi mempunyai kewajiban ialah jasa pesan permisi ataupun penjelasan yang menyangkut orang asing, senjata api serta materi peledak, dan aktivitas sosial ataupun politik warga serta SKCK dan pengawasan serta penjagaan dalam penerapan jasa pesan permisi ataupun penjelasan. Dalam penerapan kewajiban itu ada hambatan, perihal ini terjalin pada bagian Ditintelkam Subbagian Jasa Administrasi yang menyelenggarakan pelayanan pembuatan SKCK (Pesan Penjelasan Memo Kepolisian) serta pesan perizinan yang menyangkut warga dalam serta luar negara (orang asing).

Hambatan dalam aktivitas jasa paling utama dalam pencarian mengerti radikalisme yang dilaksanakan oleh Subbagian Jasa Administrasi antara lain sistem pembuatan SKCK serta pesan perizinan sedang dicoba dengan cara buku petunjuk serta informasi pemohon tidak ditaruh dalam satu penyimpanan spesial. Data-data itu ditaruh dalam satu ruangan penyimpanan arsip yang terbatas alhasil membolehkan arsip-arsip pemohon SKCK tercecer. Buat memeriksa rekapitulasi record publikasi SKCK serta pesan perizinan yang dikeluarkan oleh Kepolisian dalam dasar durasi hari, pekan, bulan serta tahun sedang belum terdapat sistem spesial yang bisa menunjukkan informasi itu dengan cara otomatis. Informasi buku petunjuk membuat kesusahan dalam mengecek silang ataupun menelusuri keluarga serta asal usul kesalahan yang sempat dicoba pemohon. Pada sistem ini, belum bisa direlasikan antara informasi pidana pemohon serta informasi keluarga. Alhasil, saat sebelum aparat menerbitkan SKCK, hingga terdapat cara dimana informasi pemohon hendak ditilik oleh sistem apakah sempat ataupun tidak melaksanakan sesuatu aksi pidana.

Pembuatan SKCK senantiasa diawasi oleh bagian intelejen. Terdapatnya Sesuatu sistem pengawasan yang bagus amat berarti serta mempengaruhi dalam cara pemberian jasa. Sebab pengawasan dikira selaku salah satu pengganti buat mengukur serta tingkatkan mutu jasa yang diserahkan. Perihal ini bisa diamati dari apa yang dikemukakan, kalau pengawasan merupakan seluruh upaya serta aktivitas buat mengenali serta memperhitungkan realitas yang sesungguhnya hal penerapan kewajiban ataupun aktivitas apakah cocok dengan apa yang sebaiknya ataupun tidak.

Andil pengawasan merupakan suatu perihal yang amat essensial serta tidak bisa diabaikan. Sebab, pada hakekatnya pengawasan merupakan sesuatu upaya buat mengetahui jasa yang dicoba oleh aparat jasa apakah jasa itu sudah menjajaki SOP yang sudah diresmikan oleh Kepolisian dan buat memperhitungkan aparat jasa dalam perihal ketaatanya serta menaati kebijakan-kebijakan yang legal. Pengawasan yang dicoba oleh Kepala Bagian jasa administrasi Ditintelkam. Ialah sesuatu keharusan buat dicoba yang bermaksud menanggulangi tiap bawahannya yang bertabiat melindungi serta pembinaan, buat menghasilkan aparat jasa yang lebih efisien serta berdaya guna. Alhasil Kepala Bagian jasa administrasi Ditintelkam bisa mengenali kegiatan-kegiatan jelas dari tiap pandangan dan kasus pelaksanaan-pelaksanaan jasa yang berikutnya pada saat terjalin kekeliruan ataupun kekurangan, bisa lekas langsung mengutip langkah-langkah koreksi serta aksi sekedarnya cocok dengan konsep yang sudah diresmikan tadinya.

Tipe pengawasan oleh Kepala Bagian jasa administrasi Ditintelkam dalam jasa pembuatan SKCK di Polda Sumbar ialah pengawasan dengan cara langsung serta 
pengawasan dengan cara tidak langsung. Impian buat melakukan pengawasan yang pas serta efisien butuh ditopang dengan mempraktikkan segi-segi pengawasan. Teknikteknik pengawasan yang ialah pandangan pantas buat diaplikasikan dalam melakukan pengawasan. Teknik-teknik pengawasan ini membagikan arahan mengenai gimana hendaknya pengawasan itu dilaksanakan. Relevan dengan perihal itu, dengan cara filosofi dikenal kalau pengawasan ialah salah satu guna manajemen yang menggenggam kedudukan yang amat berarti untuk tercapainya mutu jasa yang dijalani oleh Kepolisian. Sebab begitu juga bagusnya sesuatu sistem jasa yang dijalani tanpa terdapat pengawasan yang bagus, hingga sistem jasa itu tidak hendak terselenggara dengan bagus.

Filosofi itu teruji dalam riset ini begitu juga yang sudah dikemukakan di atas serta selaku akibat masuk akal dengan pembuktian itu hingga bila menginginkan kenaikan mutu jasa pembuatan SKCK di Polda Sumbar hingga butuh diiringi dengan pengawasan yang bagus oleh Kepala Bagian jasa administrasi Ditintelkam maksudnya pengawasan telak dibutuhkan dalam usaha buat tingkatkan mutu jasa untuk tercapainya tujuan jasa yang diharapkan serta bisa dengan cara pas mengetahui terdapatnya mengerti radikalisme di masyarakat.

\section{KESIMPULAN}

Dibuatnya suatu system elektronik yang saling terhubung dengan beberapa data paham radikal dan catatan criminal sehingga pembuatan SKCK dapat lebih akurat lagi. Pihak Ditintelkam Polda Sumbar dapat mengadakan suatu koordinasi dengan berbagai instantis terkait sehingga pembuatan SKCK sebagai salah satu cara penelusuran paham radikalisme dapat lebih optimal.

\section{DAFTAR PUSTAKA}

Tim Penyusun, Buku Panduan Mata Kuliah Kewaspadaan Nasional. Materi Pokok 2: Manajemen Konflik. Lemhannas RI. 2014

Petrus Reinhard Golose, Deradikalisasi Terorisme, Humanis, Soul Approach dan Menyentuh Akar Rumput, YPTIK, Jakarta, 2009

Wahid, e.l., Kejahatan Terorisme Perspektif Agama. Hukum, Refika Utama, Bandung, 2004

Hery firmansyah, Upaya Penanggulangan Tindak Pidana Terorime, Jurnal Mimbar Hukum, Vol. 23 No. 2. Juni 2011

WJS. Poerwaadarminta, Kamus Umum Bahasa Indonesia, Bumi Aksara, Jakarta, 2009

Membangun Sikap Waspada Bngsa Indonesia, http://www.polarhome.com/pipermail/nusantara/-/000749.html 